\title{
THE EMPLACEMENT OF THE VERMION NAPPE IN THE AREA OF KATO SELI (MT VERMION, CENTRAL MACEDONIA, GREECE)
}

\author{
Georgiadis G.A. ${ }^{1}$, Tranos M.D. ${ }^{1}$, Kilias A.A. ${ }^{1}$ and Mountrakis D.M. ${ }^{1}$ \\ ${ }^{1}$ Aristotle University of Thessaloniki, School of Geology, 54124, Thessaloniki, Greece, \\ gggk@geo.auth.gr,tranos@geo.auth.gr,kilias@geo.auth.gr,dmountra@geo.auth.gr
}

\begin{abstract}
Our fieldwork in the area of Kato Seli of Mt Vermion suggests that the Vermion Nappe is not only tectonically overlying the Maastrichtian flysch of the Pelagonian Zone, but also a Jurassic melange that overlies the Triassic-Jurassic marbles of the Pelagonian Zone. Moreover, between the Vermion Nappe and the underlying melange, tectonic slivers of meta-sandstones-meta-rudites are tectonically emplaced. This calls for a reassessment of the emplacement of the Vermion Nappe and its role in the geotectonic evolution of the area.

Keywords: Pelagonian Zone, Almopias Zone, thrusting, Tertiary.

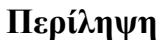

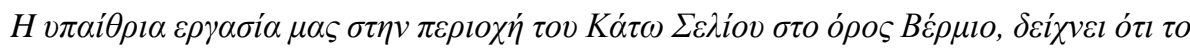

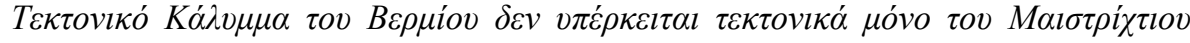

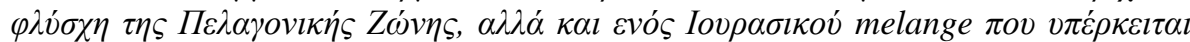

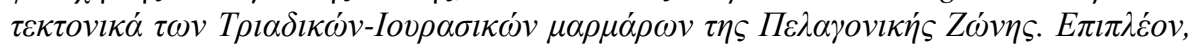

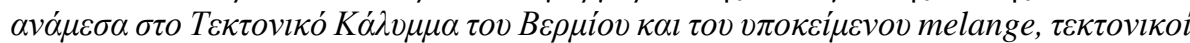

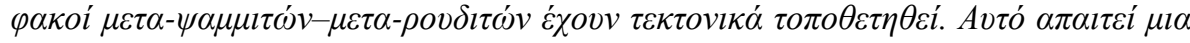

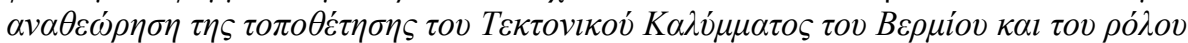

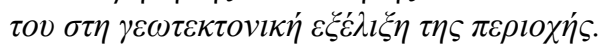

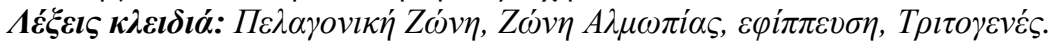

\section{Introduction}

Mt Vermion (Fig. 1) is located at Western - Central Macedonia forming along with Mt Kaimaktsalan, the Pieria mountains and Mt Olympos a NNW-SSE trending mountain range in the internal part the Hellenic orogen (Internal Hellenides) and separating the Kozani - Ptolemais basin to the west from the Thessaloniki plain to the east.

The Vermion Nappe is considered a flat-lying sheet that comprises Cretaceous sedimentary rocks and tectonically overlies the Maastrichtian flysch of the Pelagonian Zone (Brunn, 1959, 1982a, b; Braud et al., 1984). Additionally, in the area south of Kato Seli, a noteworthy issue is that the Maastrichtian flysch of the Pelagonian Zone is mapped directly overlying the Triassic-Jurassic recrystallized limestones-marbles with the Cretaceous clastic and carbonate sedimentary rocks missing (Brunn, 1959, 1982b; Braud et al., 1984). On the other hand, Photiades (2004), suggested a controversial interpretation mapping in the area of Kato Seli, the Cretaceous rocks of the Vermion Nappe to overlie not the Maastrichtian flysch, but a Jurassic melange overlying the Triassic-Jurassic marbles of the Pelagonian Zone. Moreover, according to him the Cretaceous rocks of the Vermion 
Nappe are deposited with a stratigraphic unconformity over the Jurassic melange, i.e., an unconformity that characterises the Cretaceous rocks of the Pelagonian Zone.

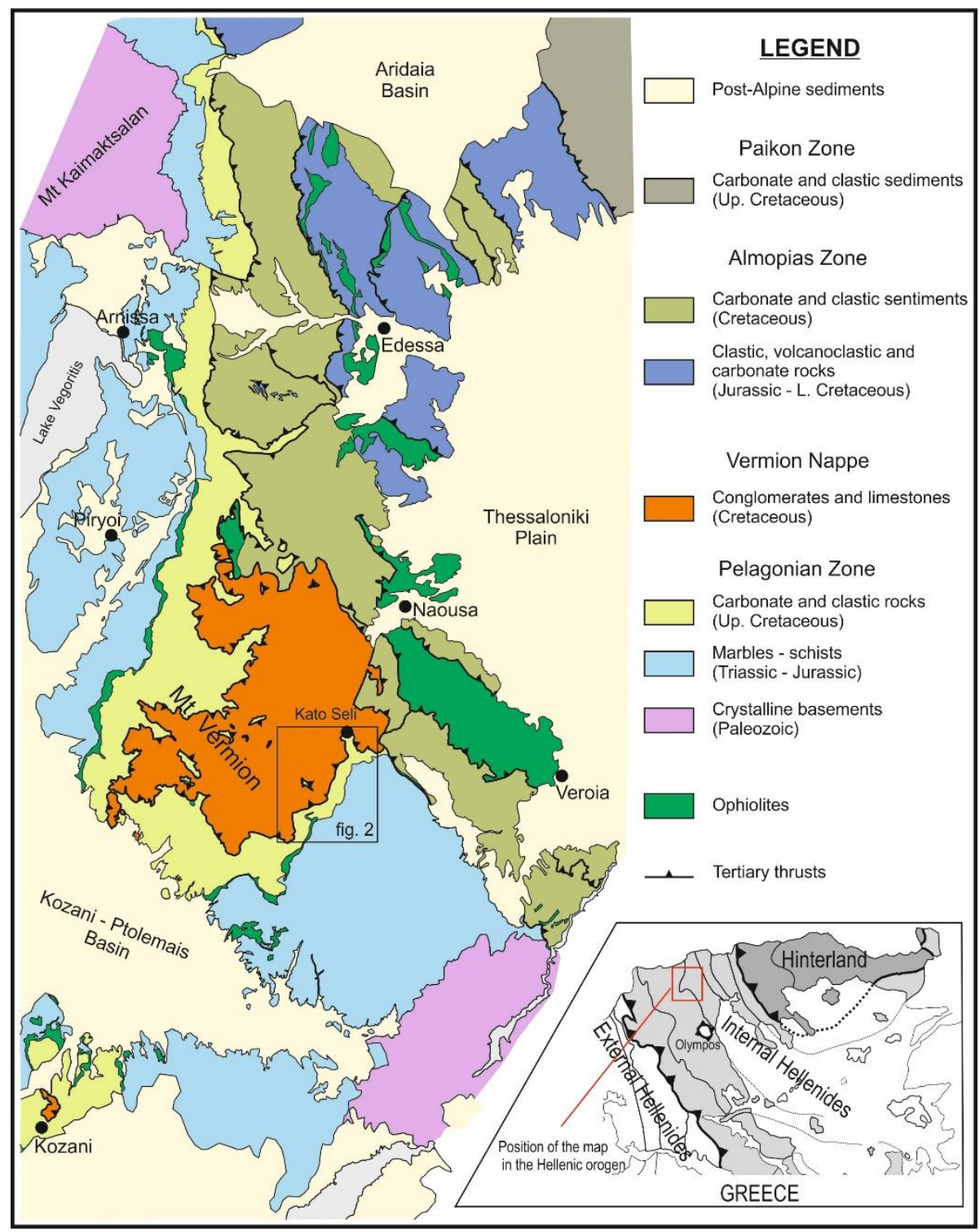

Figure 1 - Simplified geological setting of Mt Vermion and adjacent regions (modified from Anastopoulos et al., 1980; Brunn, 1982a, b; Mercier and Vergely, 1984; Mercier et al., 1988; Plastiras and Stamatis, under publication).

These controversial interpretations lead us to investigate the type of rocks and their relationscontacts in the area of Kato Seli for gaining a better understanding of the emplacement of the Vermion Nappe, and the geotectonic evolution of the area where the Pelagonian and Almopias Zones come in contact. Field work was undertaken in order to decipher the uncertainties concerning the rocks that crop-out south of Kato Seli and also the contacts of these rocks. As a result, a new geologic map of the area is presented (Fig. 2) based on our field investigations, accompanied by a geologic cross-section (Fig. 3). The new data contribute to the better understanding of the geology of the area and put new constraints on the geotectonic evolution of the wider area. 


\section{Geological Setting}

The Pelagonian Zone is considered a Mesozoic continental fragment (Mountrakis, 1986) and comprises the following rocks starting from the bottom (Mountrakis, 1984): a) a crystalline basement that includes gneisses, schists and amphibolites of Paleozoic age intruded by Upper Carboniferous granitoids; b) a meta-volcanosedimentary sequence of Permian-Lower Triassic age; c) thick carbonate sediments of Triassic-Jurassic age; d) remnants of obducted ophiolites and e) Upper Cretaceous transgressive clastic and carbonate sediments.

The Almopias Zone is the western subzone of the Axios-Vardar Zone (Kossmat, 1924); a prominent suture within the Alpine-Mediterranean orogenic belt running parallel to the Hellenide-Dinaride orogenic belt in northern Greece and former Yugoslavia respectively. It comprises the following rocks (Mercier, 1968; Mountrakis, 1976; Brown and Robertson, 2004; Galeos et al., 1994): a) Paleozoic basement rocks (gneisses, marbles, schists), b) Triassic-Jurassic marbles and schists, c) Mesozoic emplaced ophiolites, d) Upper Jurassic-Lower Cretaceous clastic, volcanoclastic and carbonate sediments, and e) Middle-Upper Cretaceous transgressive carbonate and clastic sediments. These rocks form a series a West-directed imbricates (Fig. 1). Each imbricate comprises only some of the above mentioned rocks forming a differed unit that is not always possible to be correlated with its neighbouring units-imbricates.

More precisely the western and southern parts of Mt Vermion are made up of rocks that belong to the Pelagonian Zone while the rocks that crop-out in the central and eastern part of the mountain are considered to belong to the Almopias Zone (Fig. 1). In the central part of Mt Vermion a flat-lying nappe, namely the Vermion Nappe, was identified to tectonically overlie the Upper Cretaceous transgressive sediments of the Pelagonian Zone and more specifically the Maastrichtian flysch (Brunn, 1959). The Vermion Nappe is made up of conglomerates (often red colored at their base) and limestones (Brunn, 1982a, b; Braud et al., 1984). Its base is considered to be Aptian-Albian but the sedimentation continuous in the Upper Cretaceous as well (Brunn, 1982a, b; Braud et al., 1984).

The geotectonic evolution of this part of the Hellenic orogen was studied by numerous researchers (Nance, 1981; Mountrakis, 1983; Vergely, 1984; Kilias and Mountrakis, 1989; Doutsos et al., 1993; Kilias et al., 2010; Avgerinas, 2014). The structures and kinematics of the deformational events reported in the above mentioned studies are sometimes controversial but generally two major orogenic phases are recognized. The first orogenic phase (Eo-Hellenic) took place during the Upper Jurassic-Lower Cretaceous and is related to the obduction of the ophiolites from the Axios Zone on the Pelagonian fragment. During this orogenic phase greenschist-amphibolite facies metamorphism affected the Mesozoic sediments of the Pelagonian and Almopias Zones and the already metamorphosed basement rocks. The second orogenic phase (Neo-Hellenic) is related to the collision of the Apullian plate with the Eurasian margin during the Tertiary and the formation of the Alpine Hellenic orogen. The West-directed imbricates of the Almopias Zone formed during this orogenic phase. The Tertiary orogenic phase was followed by a post-orogenic extension that formed basins that was filled with terrestrial sediments.

\section{Geology and structural elements of the area of Kato Seli}

Based on our fieldwork including the geological mapping of the area of the Kato Seli at scale $1: 25.000$, detailed geological cross-sections, and recording of the deformational structures in the different map units, we define the following geological and structural elements in the area of Kato Seli. 


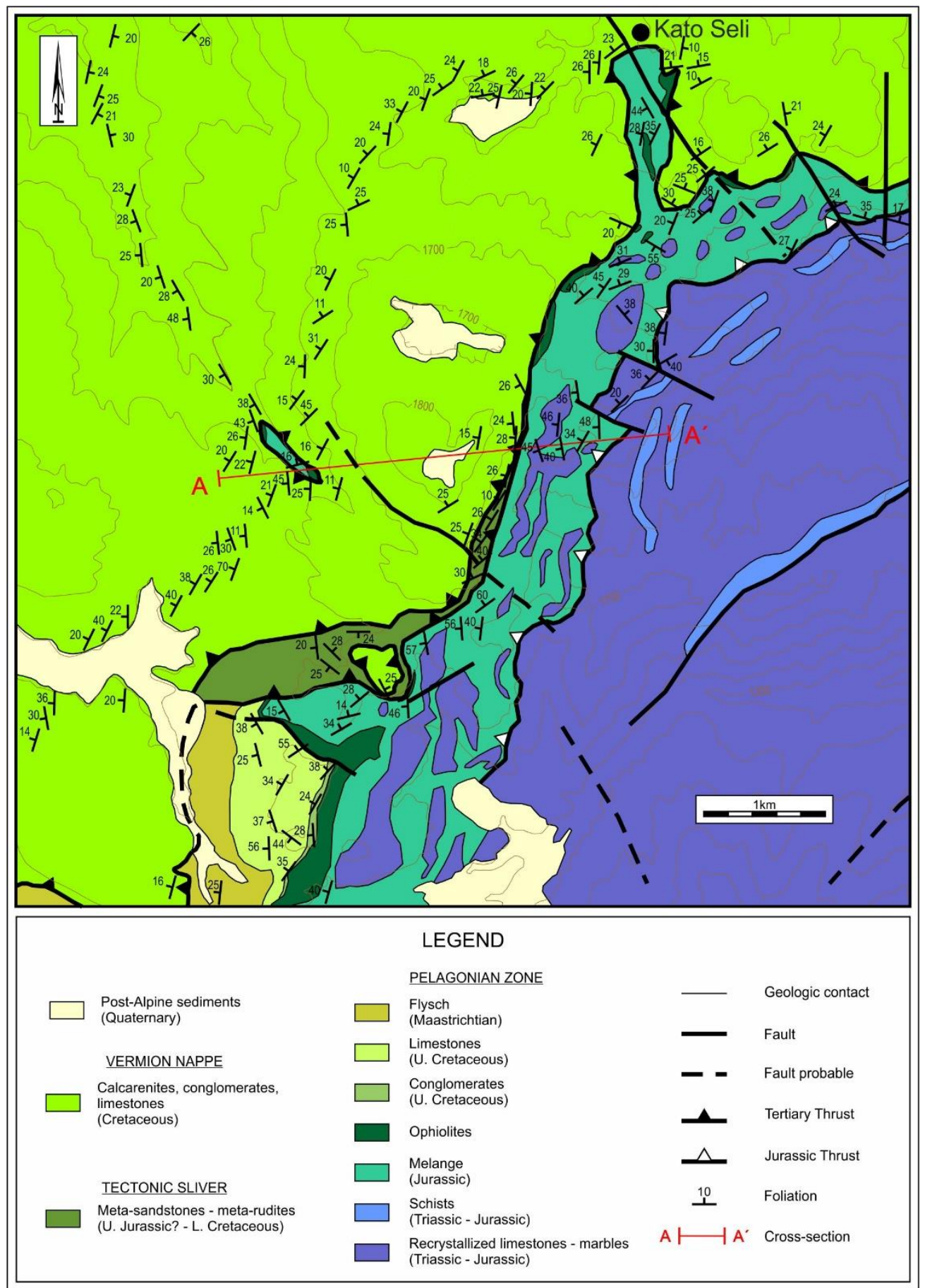

Figure 2 - Geological map of Kato Seli.

\subsection{Geologic Map Units}

\subsubsection{Pelagonian Zone Units}

- Triassic-Jurassic marbles and schists. This unit comprises gray, light gray and white recrystallized limestones-marbles. They are often dolomitic and are part of the Triassic- 
Jurassic neritic, platform limestones that overlie the metamorphic basement of the Pelagonian Zone (Brunn, 1959; Mountrakis, 1983; Kilias and Mountrakis, 1989; Sharp and Robertson, 2006). Green chloritic-serikitic schist horizons up to a few meters thick that represent metamorphosed clastic sediment intercalations are found mostly at the upper part of the marbles (Figs. 2, 3).

- Jurassic melange. A Jurassic melange consisting of green-brown colored chloritic-sericitic schists and phyllites (Figs. 2, 3, 4c) is tectonically overlying the Triassic-Jurassic marbles. It is considered a melange because of (a) the existence of large blocks of recrystallized limestones which are floating as olistholites (Figs. 2, 3, 5a), (b) its intense deformation i.e., folded with tight-isoclinal folds (Fig. 5e), (c) the existence at the upper part and the top of the melange of ophiolites of up to a few meters thick of mainly serpentinitic composition that appear as floating lensoidal bodies (Figs. 2, 3). They are clastic sediments that were formed and metamorphosed during the emplacement of the ophiolites during the Upper Jurassic (Mountrakis and Soulios, 1978; Sharp and Robertson, 2006).

- Upper Cretaceous transgressive sedimentary rocks. The Upper Cretaceous transgressive sedimentary rocks of the Pelagonian Zone are found at the southwest part of the mapped area overlying the ophiolites starting with pebble-cobble, poorly sorted polymict conglomerates (marble, ophilite and schist clasts). The conglomerates are up to $40 \mathrm{~m}$ thick and pass upwards to gray-dark gray, fossiliferous limestones. The limestones are neritic and medium- to thickbedded. Towards the top, they become thin-bedded, clastic, and pass to flysch. The flysch is brown-light brown and consists of very thin to thin siltstone and sandstone turbiditic intercalations. The age of the flysch is Maastrichtian (Brunn, 1959, 1982a; Mercier, 1968). The Upper Cretaceous sedimentary rocks dip to the West with intermediate angles (Fig. 2) as the Maastrichtian flysch, while the latter is tectonically overlain by the Vermion Nappe (Fig. 2).

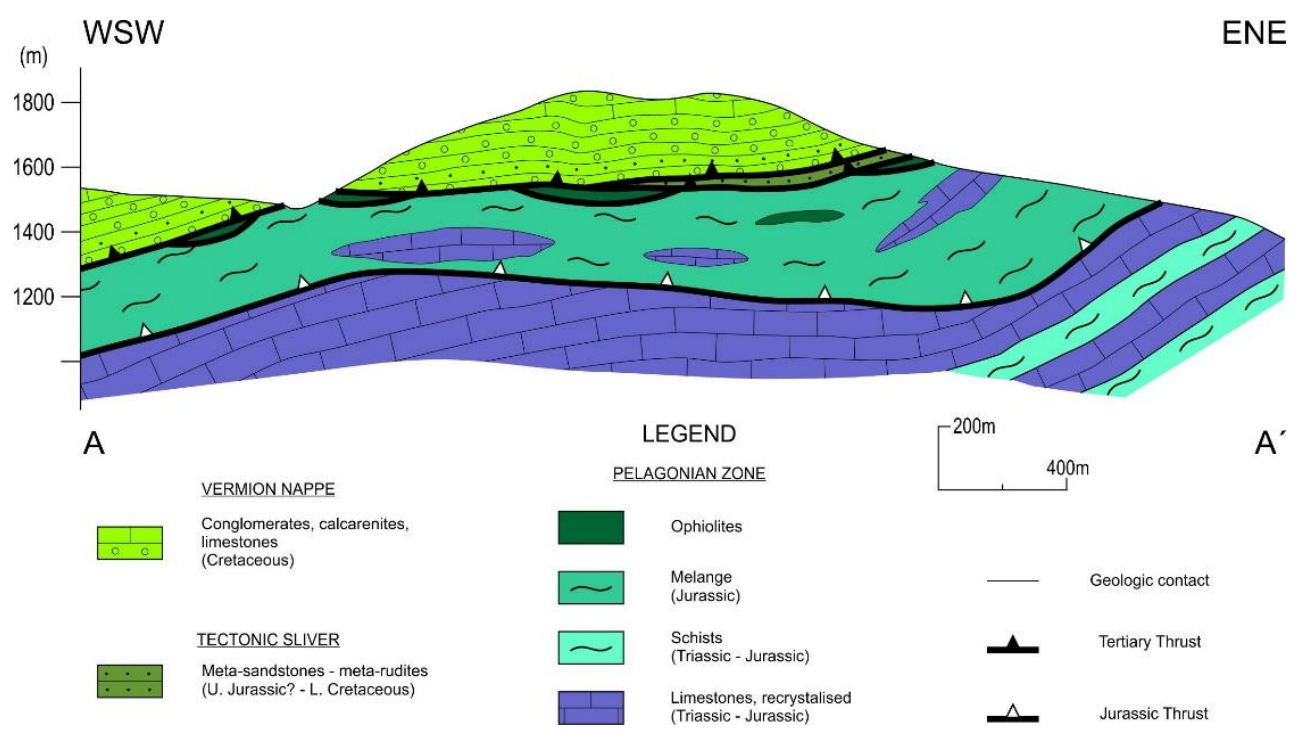

Figure 3 - Geologic cross-section at the Kato Seli area, see Fig. 2 for position.

\subsubsection{Meta-sandstones-meta-rudites}

Greenish brown to brown, thin- to medium-bedded rudites and sandstones with few thin- bedded, green colored, pelitic intercalations that have been subjected to low grade metamorphic facies. The rudites contain quartz, ophiolite, schist and carbonate clasts ranging in size from granules to pebbles. Upwards, these rocks pass to beige-gray colored calcirudites and calcarenites because the carbonate clasts become more abundant. The thickness of this unit does not exceed $30 \mathrm{~m}$ and wedges out 
towards the north (Figs. 2, 5a). These rocks are heterogeneously deformed during Tertiary, with a strong developed mylonitic foliation parallel to bedding at parts. These rocks resemble similar lithological features with metaclastic rocks mapped more easterly as "flyschoidal rocks", and which have been included in the "zone broyée" mentioned in the geological map of IGME - Veroia sheet (Brunn, 1982b). Braud et al. (1984), assigned a Late Jurassic(?)-Early Cretaceous age to these rocks.

\subsubsection{Vermion Nappe}

- Interbeds of reddish-pinkish colored calcarenites-conglomerates. They are calcarenites and polymictic conglomerates in interbeds that have a distinct reddish, pinkish color (Fig. 4d). These rocks are found at the base of the Vermion Nappe and their thickness varies from a few meters up to about 50m. The conglomerates are medium- to thick-bedded, poorly sorted and clast- to matrix-supported. They contain white, gray and dark gray recrystallized limestone-marble, ophiolite and schist clasts varying in size from granules to cobbles. The clasts are angular to rounded and at places pressure-solution resulted in convex/concave contacts between them. Both normal and reverse grading was observed. The calcarenites vary from fine- to very coarse-grained and are thin to medium bedded with calcite cement. The onset of the deposition of these rocks is considered as Early Cretaceous, and more specifically Aptian-Albian based on descriptions of exposures of the base of the Vermion Nappe at other locations (Brunn, 1982a, b; Braud et al., 1984).

- Greyish conglomerates-calcarenites-limestones. These rocks overlie the previous interbeds and comprise mainly conglomerates with intercalations of calcarenites and limestones. The color of these rocks is gray to dark gray. The conglomerates are thick to very thick bedded, moderately to well sorted, clast-supported with calcarenitic matrix and calcite cement (Fig. $4 \mathrm{e}$ ). The clasts are rounded to well-rounded recrystallized limestones-marbles ranging in size from pebbles to cobbles. Normal and reverse grading was recorded among the beds. The calcarenites are thin- to medium-bedded and medium- to coarse-grained. Normal grading was recorded at some occasions. The limestones are neritic, thin- to medium- bedded, often clastic, and in places with abundant shell and gastropod fossils (Fig. 4f). The age of these rocks is Late Cretaceous (Brunn, 1959, 1982a, b; Braud et al., 1984).

\subsection{Structural elements along the contact of the Vermion Nappe and the Jurassic melange}

Concerning the contacts between the mapped rocks, our observations suggest that the contact between the overlying Cretaceous rocks and the underlying ones is sub-horizontal near Kato Seli, but to the SW, it trends NE-SW dipping to the NW with low angles (Fig. 2). The main foliation of the Triassic-Jurassic marbles is sub-parallel to the main foliation of the Jurassic melange and dips to the NW with intermediate angles (Figs. 2, 6a). On the other hand, the bedding of the overlying rocks generally dips to the NW with low angles (Figs. 2, 6b).

The Cretaceous rocks of the Vermion Nappe overlie to the west the Maastrichtian flysch, but in the study area the Jurassic melange. The contact of the Cretaceous rock of the Vermion Nappe with the underlying Jurassic melange is tectonic as suggested by the intense shearing parallel to the bedding of the Cretaceous rocks close to this contact. Similar shearing parallel to bedding is observed in the meta-sandstones-meta-rudites that are mapped as tectonic slivers between the Vermion Nappe and the melange. The shearing is more intense and pronounced close to the contact with the tectonically underlying ophiolites and melange rocks. The amount of deformation varies between the rock types with the finer grained rocks being more intensely deformed. A mylonitic foliation is developed at places with sedimentary clasts being elongated along it (Fig. 4b) forming a well preserved stretching lineation that trends NE-SW to ENE-WSW (Fig. 6c). The abundant presence of $\sigma$-clasts serves as a good indicator for a top-to-WSW direction of shearing (Figs. 5c, d). The deformation took place at semi-brittle-semi-ductile conditions and the deformed rocks are to some extent dynamically recrystallized. The ophiolites that are directly below the contact are also sheared with the top-to- 
WSW shearing as defined by stretching lineations similar in direction with those of the overlying rocks. That the ophiolites are mainly serpentinites probably served as a lubricant during the shearing. Only small lensoid-shaped ophiolitic bodies are found below the contact possible because a part of the ophiolites was scraped off during the shearing. This is also indicated by the small ophiolitic slivers found between the tectonic contact of the Vermion Nappe and the Maastrichtian flysch to the west of the mapped area as seen at the Piryoi geologic map sheet of IGME (Brunn, 1982a). In the SW part of the mapped area the ophiolites that underlie the Upper Cretaceous trangressive sediments of the Pelagonian Zone are more massive and continuous.
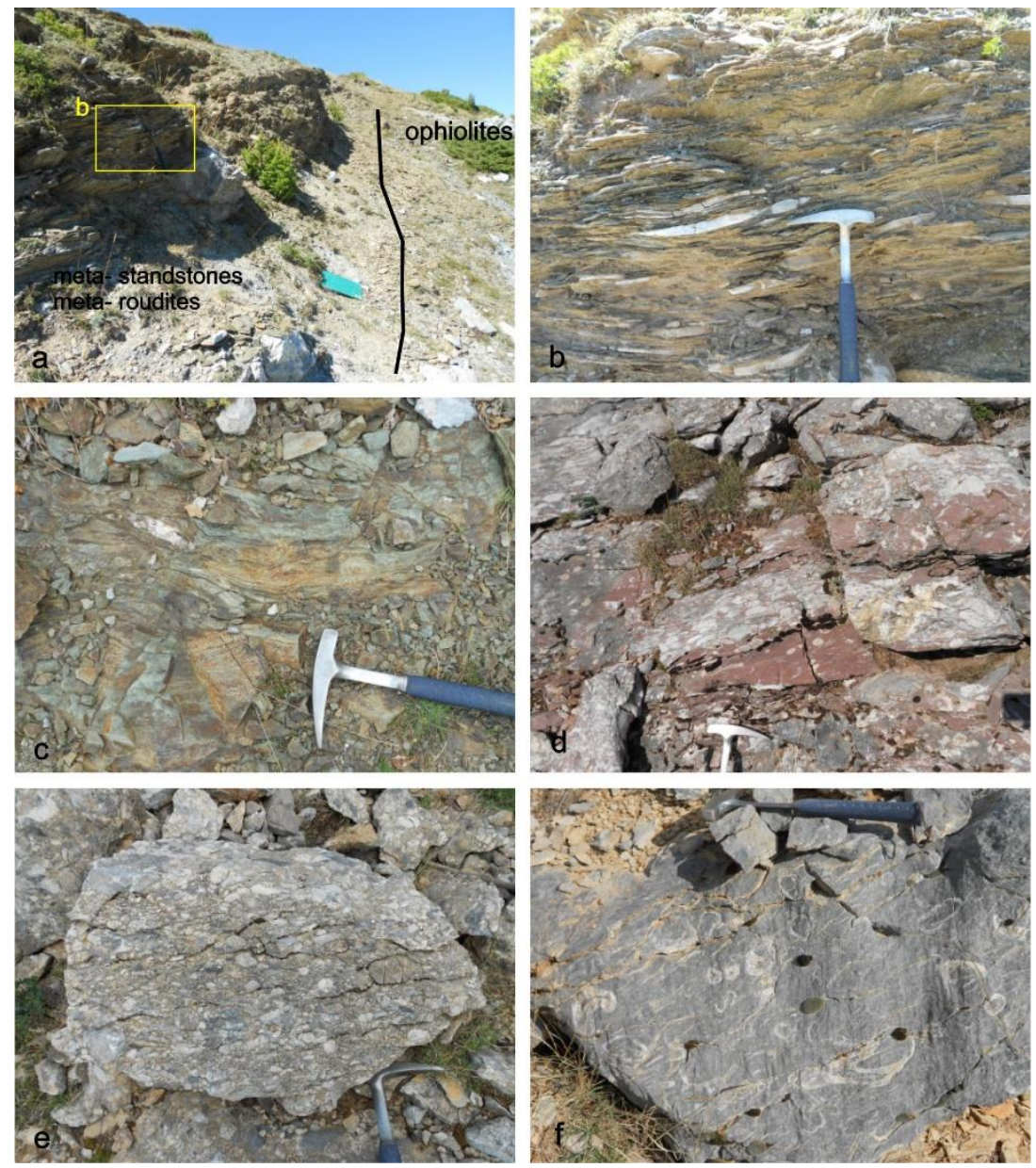

Figure 4 - Field photos: a) contact of the meta-sandstones-meta-rudites with the underlying ophiolites; b) a detail of the meta-sandstones-meta-rudites in fig. 4a, the elongated clasts attest to the tectonic nature of the contact in fig. 4a; c) the Jurassic melange; d) interbeds of reddish conglomerates-calcarenites at the base of the Vermion Nappe; e) the Upper Cretaceous conglomerates of the Vermion Nappe; f) Upper Cretaceous fossiliferous limestones of the Vermion Nappe. 

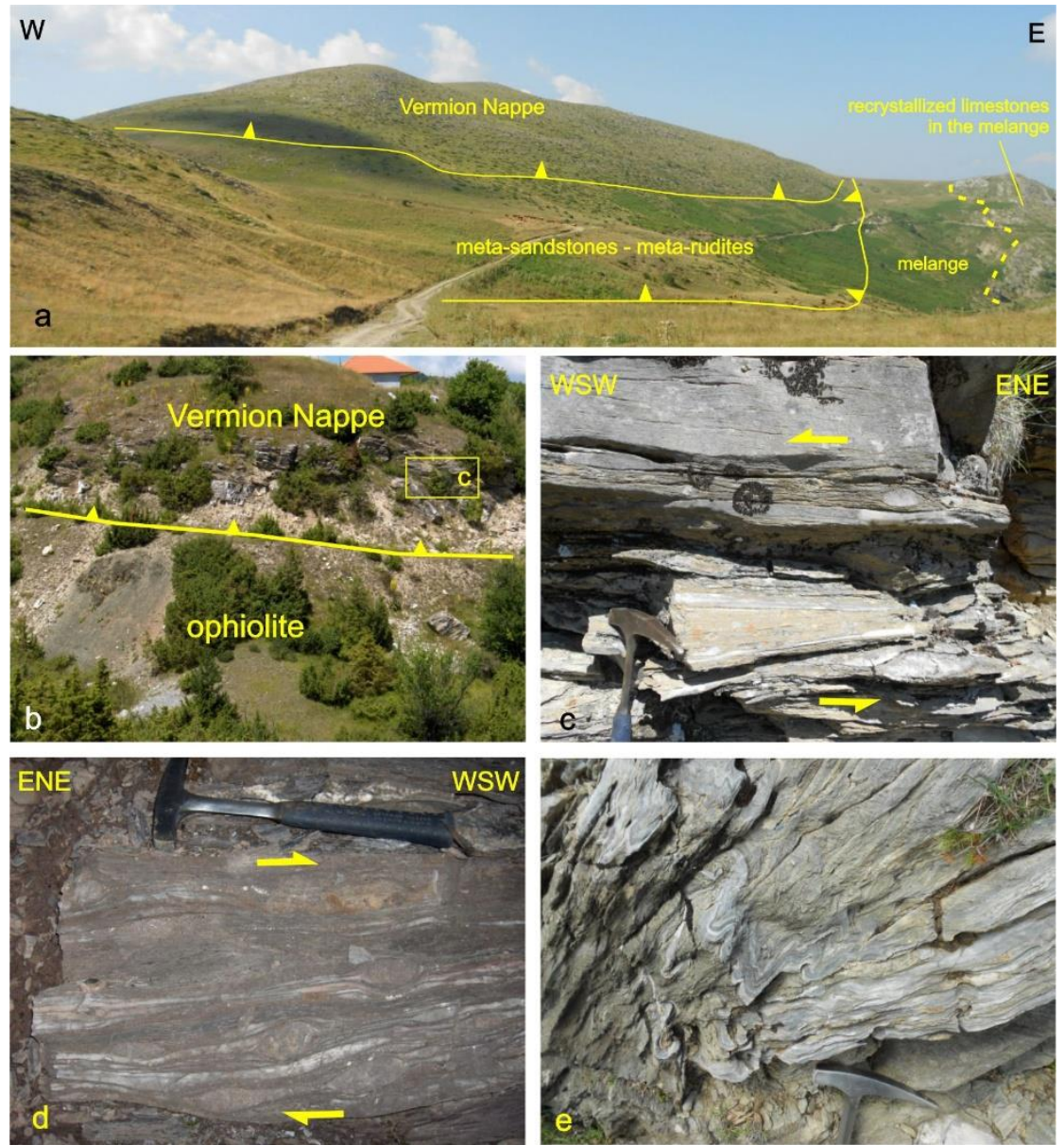

Figure 5 - Field photos: a) panoramic view, looking N, showing the relations of the rocks in the mapped area, the mountain peak in the centre of the photo is located approximately at

the centre of the map in fig. 2; b) contact of the Vermion Nappe with the underlying ophiolites close to Kato Seli; c) a close view of the rocks above the tectonic contact in fig. 5b; d) deformed conglomerate, at the base of the Vermion nappe showing top-to-WSW direction of shearing; 5e) tight folds in the Jurassic melange.

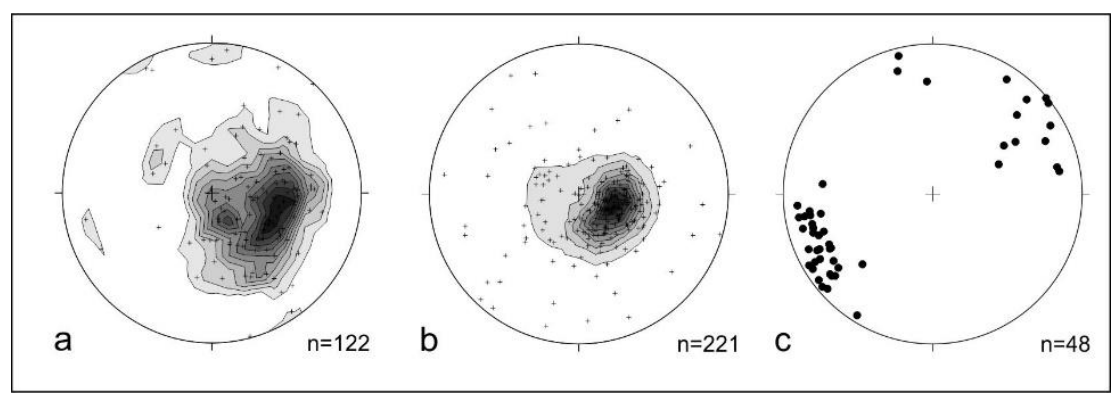

Figure 6 - Stereographic projections (equal area, lower hemisphere), using the StereoNett program (Duyster, 2000). a) main foliation of the Triassic-Jurassic marbles and the Jurassic melange, b) bedding in the Vermion Nappe, c) stretching lineation close to the tectonic contact at the base of the Vermion Nappe and the meta-sandstones-meta-rudites. 


\section{Discussion - Conclusions}

The new data gathered in the area of Kato Seli show that the Vermion Nappe consists of Cretaceous sedimentary rocks that overlie tectonically not only the Maastrichtian flysch of the Pelagonian Zone as occurs to the west of the region, but also the ophiolites and Jurassic melange that in turn tectonically overlies the Triassic-Jurassic marbles of the Pelagonian Zone. The direction of emplacement of the Vermion Nappe is to the WSW, which is in accordance with the kinematics reported for the area of Western-Central Macedonia during the Tertiary orogenesis (Mountrakis, 1983; Vergely, 1984; Kilias and Mountrakis, 1989; Kilias et al., 2010; Avgerinas, 2014). Tectonic slivers of rocks such as meta-sandstones-meta-rudites have been mapped in the base of the Vermion Nappe and they are intensely deformed with the same top-to-WSW shearing. Until now the Vermion Nappe was depicted to overlie only the Maastrichtian flysch (Brunn, 1959, 1982a, b; Anastopoulos et al., 1980; Braud, 1984) or to have been unconformably deposited as the other Upper Cretaceous transgressive sediments of the Pelagonian Zone (Photiades, 2004). However, the new data presented here show that the Vermion Nappe is tectonically overlying both the Maastrichtian flysch of the Pelagonian Zone and the Jurassic melange; a fact that should be considered in any geotectonic scenario about the Internal Hellenides concerning the boundary between the Pelagonian and Almopias Zones.

\section{References}

Anastopoulos, I., Koykoyzas, K. and Faugeres, L., 1980. Geological map of Greece - 1:50.000 Kozani sheet, IGME.

Avgerinas, A., 2014. Analysis of deformation and kinematics of the Pelagonian Zone in Northern Greece, PhD Thesis, Aristotle University of Thessaloniki, 365 pp. (in Greek with English summary).

Braud, J., Brunn, J., Campion, G., Didelot, J., Fourmaintraux, D., Lemaitre, J., Mercier, J., Pichon, J. and Vergely, P., 1984. La chaine du Vermion, ses nappes et sa bande broyée, Bull. Soc. Geol. France, XXVI, 713-717.

Brown, S.A.M. and Robertson, A.H.F., 2004. Evidence for Neotethys rooted within the Vardar suture zone from the Voras Massif, northernmost Greece, Tectonophysics, 381, 143-173, doi: 10.1016/j.tecto.2002.06.001.

Brunn, J., 1959. Zone du Vardar et zone Pelagonienne en Grece, Compte Rendu Sommaire des Séances de la Société Géologique de France, 6, 138-139.

Brunn, J., 1982a. Geological map of Greece - 1:50.000 - Piryoi sheet, IGME.

Brunn, J., 1982b. Geological map of Greece - 1:50.000 - Veroia sheet, IGME.

Doutsos, T., Pe-Piper, G., Boronkay, K. and Koukouvelas, I., 1993. Kinematics of the central Hellenides, Tectonics, 12, 936-953.

Duyster, J., 2000. StereoNett Version 2.46.

Galeos, A., Pomoni-Papaioannou, F., Tsaila-Monopolis, S., Turnsek, D. and Ioakim, C., 1994. Upper Jurassic - Lower Cretaceous "molassic-type" sedimentation in the western part of Almopia subzone, Loutra Aridhea Unit (northern Greece), Bull. Geol. Soc. Greece, XXX, 171-184.

Kilias, A., Frisch, W., Avgerinas, A., Dunkl, I., Falalakis, G. and Gawlick, H.-J., 2010. Alpine architecture and kinematics of deformation of the northern Pelagonian nappe pile in the Hellenides, Austrian J. Earth Sc., 103/1, 4-28.

Kilias, A. and Mountrakis, D., 1989. The Pelagonian Nappe, tectonics, metamorphism and magmatism, Bull. Geol. Soc. Greece, XXIII/1, 29-46 (in Greek with English abstract).

Kossmat, F., 1924. Geologie der Zentralen Balkanhalbinsel: Die Kriegsschauplätze 1914-1918, geologisch dargestellt, 12, Berlin, Bornträger, 198 pp.

Mercier, J., 1968. Etude geologique des zones Internes des Hellenides en Macedoine centrale. Contribution a l' étude du metamorphisme et de l' évolution magmatique des zones internes des Hellenides, Ann. Géologique des Pays Hélléniques, 20, 1-739.

Mercier, J. and Vergely, P., 1984. Geological map of Greece - 1:50.000 - Edhessa sheet, IGME. 
Mercier, J., Vergely, P. and Galeos, A., 1988. Geological map of Greece - 1:50.000 - Arnissa sheet, IGME.

Mountrakis, D., 1976. The northern boundary of the Axios and Pelagonian zones in the area of K. Loutraki - Orma (Almopia), PhD Thesis, Aristotle University of Thessaloniki, 164 pp. (in Greek with English summary).

Mountrakis, D.M., 1983. Structural geology of the North Pelagonian zone s.l. and geotectonic evolution of the internal Hellenides, Habilitation Thesis, Aristotle University of Thessaloniki, 289 pp. (in Greek with English summary).

Mountrakis, D., 1984. Structural evolution of the Pelagonian Zone in northwestern Macedonia, Greece. In: Dixon, J.E. and Robertson, A.H.F., eds., The Geological Evolution of the Eastern Mediterranean: Geological Society of London, Special Publication, 17, 581-590.

Mountrakis, D., 1986. The Pelagonian zone in Greece: a polyphase-deformed fragment of the Cimmerian continent and its role in the geotectonic evolution of the eastern Mediterranean, The Journal of Geology, 94, 335-347.

Mountrakis, D. and Soulios, G., 1978. On a thrusted schistoradiolaritic formation with ophiolites and the presence of ophiolitic melanges in the area of Arnissa. Their significance on the tectoorogenic evolution of the Pelagonian Zone, Bull. Geol. Soc. Greece, XIII/2, 18-33 (in Greek with France summary).

Nance, D., 1981. Tectonic history of a segment of the Pelagonian zone, northeastern Greece, Canadian Journal of Earth Sciences, 18, 1111-1126.

Photiades, A., 2004. Geological mapping revision of the Vermion Mountain (Internal Hellenides, Greece). In: Chatzipetros, A.A. and Pavlides, S.B., eds., 5th International Symposium on Eastern Mediterranean Geology, Thessaloniki, 161-164.

Plastiras, V. and Stamatis, A., (under publication). Geological map of Greece - 1:50.000 - Velvendos sheet, IGME.

Sharp, I.R. and Robertson, A., 2006. Tectonic-sedimentary evolution of the western margin of the Mesozoic Vardar Ocean: evidence from the Pelagonian and Almopias zones, northern Greece. In: Robertson, A.H.F.F. and Mountrakis, D., eds., Tectonic Development of the Eastern Mediterranean Region: Geological Society of London, Special Publication, 260, 373-412.

Vergely, P., 1984. Tectonique des Ophiolites dans les Hellénides Internes (déformations, métamorphismes et phénomènes sédimentaires). Conséquences sur l'évolution des régions téthysiennes occidentales, $\mathrm{PhD}$ Thesis, Université Paris-11, Orsay, 661 pp. 